\title{
Effective Instructions in Design Process of Urban Public Spaces to Promote Sustainable Development
}

\author{
Mohsen Sanei ${ }^{1}$, Mina Khodadad ${ }^{1}$, Farid Panahi Ghadim² \\ ${ }^{1}$ Department of Architecture, Politecnico di Milano University, Milan, Italy \\ ${ }^{2}$ Department of Geography and Planning, University of Tabriz, Tabriz, Iran \\ Email: mohsen.sanei@mail.polimi.it
}

How to cite this paper: Sanei, M., Khodadad, M. and Ghadim, F.P. (2017) Effective Instructions in Design Process of Urban Public Spaces to Promote Sustainable Development. World Journal of Engineering and Technology, 5, 241-253.

https://doi.org/10.4236/wjet.2017.52019

Received: March 14, 2017

Accepted: May 8, 2017

Published: May 11, 2017

Copyright $\odot 2017$ by authors and Scientific Research Publishing Inc. This work is licensed under the Creative Commons Attribution International License (CC BY 4.0). http://creativecommons.org/licenses/by/4.0/

\section{Open Access}

\begin{abstract}
Public spaces in cities have long been the basis used for the expression of cultural values and social relations. Cultural and social systems have an old two-sided relation. This means that the establishment and continuity of social relationships strengthen the values and norms; on the other hand, culture determines the conditions and the formation of social relationships. Therefore, to create a bonding connection between people and the city, urban public spaces are the focal points which still need to be noticed more effectively by designers and managers. There are components which help the designers design more efficient urban public spaces and, as a consequence, there will be more vitality in cities. In today conditions, sustainability issues, as the solutions of having better future conditions, can considerably affect these components and give the society the opportunity of having more capable public spaces. Sum of studies in the field of sustainability and the subsequent sustainable public spaces researches mainly express three components of environment, economy and society, among which environment section is more significant than two others, so that the importance of climatic design components has been tangibly noted in public space designing. The aim of this paper is reviewing urban public spaces and sustainability notions and, as the result, reaching to some instructions for designing sustainable urban public spaces which have important impacts on these types of places. By doing this, not only the possibility of getting closer to the identity of cities, but also the necessary ground for the strong presence of sustainable urban public spaces in cities, are provided. The research method is descriptive-analytic and library research method is used for data collecting.
\end{abstract}

\section{Keywords}

Public Space, Urban Public Space, Sustainability, Sustainable Development 


\section{Introduction}

Initially, in sustainable development topics, most emphasis was on economic and environmental issues and social issues were less important but these days social sustainability is one important aspect of sustainable development alongside economic and environmental dimensions in the cities, which can shape the basis of a sustainable city in which citizens can live together in harmony based on their participation, sense of belonging, civil society, identity, etc. Social sustainability involves concepts such as sense of belonging, participation, identity, dependence to place and more. Meanwhile, the city's public spaces, as they belong to all citizens and they can have access to these places without any discriminations (gender, race, ethnicity, socio-economic level) and limitations, can play a very important role in social sustainability. Such areas cause social interactions as prerequisite of convergence, sense of belonging and participation, and in consequence, social sustainability as an undeniable necessity in the continuity of sustainable urban development.

As it is known, culture and social relations prevailing in a society influence the architecture of that society and apart from environmental impacts, they have desired effects in construction and architecture and make it more specific. The scope of this research ranges between architecture and society. As it will become clear later, in this article, public space as a container for community relations at every level of the society, and the people and social relations as its forming elements are assumed. Features such as creating identity in the space, generating a sense of place and belonging to the space, flexibility and enhancing environmental quality can be effective in stability of space. Social sustainability plays an important role in finding solutions for having more effective interactions between social groups. Sustainable design can lead to the formation of sustainable architecture; afterward, by using the principles of social stability and investigating the relationship between this approach and public space, it can provide the ground for creating social relations and activities and promoting the culture and art in the city with the goal of leading to a sustainable community.

This article tries to study the role of public space in strengthening social interactions (participation and sense of belonging), which leads to social sustainability. First, theoretical grounds and related literatures are reviewed. Then, the main concepts of urban public spaces and sustainable architecture, and the relation between them are studied. As results, some instructions are presented, as the main instructions, which are needed to have sustainable urban spaces. The research method is descriptive-analytic and library research method is used for data collecting.

\section{Theoretical Foundations}

Urban public spaces are important elements of the modern cities. These spaces, in different parts of human life, play a vital role [1]. Hence, allocation and efficient use of these spaces is a fundamental issue that must be considered in stud- 
ying the lives of people residing in cities [2].

The use of urban public spaces is an experience which is not similar for everyone and factors such as age, gender, community groups and ethnic-racial minorities influence the understanding of urban life [3]. To achieve these factors' roles in the impact of city on humans, understanding the impact of urban public space on the networks of social relations is required [4]. In this context, many studies have confirmed that residents of urban areas tend to match the residence location with the areas including urban public spaces [5]. Therefore, the design features of urban public spaces are important factors promoting social activities in urban society. These strong social relations in urban society can create an environment which comes along relation, meaning and purpose, and also construct the basis for sustainable social development [6].

The role of public spaces in sustainable social development can be important in this sense that today, human societies, due to daily quantitative and qualitative growth and development which has led to the construction of large and densely populated cities, are facing with new problems. The frequency and density of disparate and heterogeneous cities, despite the physical proximity, has increased the social distance between people day by day and along with it, the solidarity, communication and attention of the people to each other is reduced [4]. Hence, the human need for socializing, makes him needful to have spaces for exchanging thoughts and ideas. From this perspective, urban public spaces are places that are leading to sustainable social development; therefore, the quantity and quality of buildings and urban public spaces, sometimes referred to as civic or urban buildings, is one of the most important indicators of the city capability to meet the social needs of citizens [7]. So, today in urban development programs, public spaces, have become essential, which suggests the role of these spaces in strengthening the cultural-social aspects of the city. In other words, urban spaces as parts of a city, are considered as the public arena and the public activities exhibition [3].

\section{Literature Review}

Few studies have been written in the field of public spaces role in sustainable social development. Most of studies are done to assess the condition of public spaces. However, in the following, the most important experimental studies related to the present study are expressed: Perovic and Folic (2012), by examining the social function of urban public spaces, have counted security, availability, regularly organizing, calmness, having meeting places and being able to walk, as the most important factors of them and characterized the lack of attractiveness, lack of visual beauty and visual disturbances, as the worst indicators [8]. According to the study of Jalaladdini and Oktay (2012), the most significant function of public spaces, from social perspective, is hiking and tourism value, which leads to vitality and vibrancy [9]. From Turel et al. (2007) perspective, the most vital problems of urban public spaces are respectively: lack of walking possibility, pollution, insecurity, repairs and maintenance failure, traffic and socio-cultural 
problems [10]. In the study of Mohammadi et al. (2012), the most effective difficulties of urban public spaces on social relations of groups are mentioned as being public, participatory and a place for meeting [11]. Fathi (2012), arrived to the conclusion that modern urban public spaces affect the social relations network during the time and sustainable social relations are the products of sustainable urban spaces [4].

\section{The Concept of Urban Public Space}

Urban Space is a social, cultural and physical issue, which depends on activity patterns of social groups [12]. Urban public space, since Agora management in Greece and the Roman Forum, has been a focus point of urban planners for centuries; however, for the specific reasons of urban planning during modern urban development, less attention was upon urban public spaces. In this period, many of public open spaces were ignored or lost their functions or faced with changing the prospects [8]. Recently, the public space, with the aim of moving towards a healthy urban environment, becomes the focus point of sociologists, geographers, political scientists and urban planners [9]. Therefore, public spaces are considered as social spaces, such as city squares, Plazas, parks and streets, which are open and accessible to anyone, regardless of their gender, race, age and economic levels, without any difficulties [13].

Rahnamai and Ashrafi (2007) define public spaces as those types of spaces that all citizens have the right to enter and being there, without the need to be controlled. Spaces such as streets, parks, squares, markets and mosques, due to their performance scale and broad and diverse range of audiences, contribute in communal life of citizens. Hence qualitative promoting of these types of spaces, will create a healthy and vivid urban community, more than other types of spaces [24]. Turel et al. (2007) name public spaces as places in which private and public requirements appear, so during whole social life, there is a dynamic balance between public and private activities [10]. Walzer (1986), has defined public spaces as spaces of thinking, because they are designed for various uses, including foreseen and unforeseen applications [25]. Lipton (2003), describes public spaces as open-air living rooms and recreation and leisure centers outside the houses [26]. Woolley (2003), believes that physically, public spaces are like urban productive devices, components and communication channels with environmental, morphological and esthetical values [27]. Different criteria of public spaces, can be seen in Table 1, which are defined by some of the most known theorists of this field.

\section{Species of Urban Public Spaces}

External public spaces include the parts that are between private buildings such as streets, squares, parks, highways, parking lots, sides of rivers, lakes and coasts. Internal public spaces are also some internal spaces like public institutions, such as libraries, museums and city halls, and the buildings related to public transportation, such as bus and train stations and airports. Some of the spaces which 
Table 1. Indicators of urban public space.

\begin{tabular}{|c|c|c|}
\hline Theorist & Year & Criteria in urban public spaces \\
\hline $\begin{array}{c}\text { Jacobs J. } \\
{[14]}\end{array}$ & 1961 & $\begin{array}{l}\text { Order activity on visual order, mixed use, permeability, possibility of } \\
\text { monitoring and caring, diversity and richness of activities, } \\
\text { paying attention to Streets, the possibility of social incorporation, } \\
\text { the richness of activities, flexibility. }\end{array}$ \\
\hline $\begin{array}{c}\text { Lynch K. } \\
\quad[15]\end{array}$ & 1981 & Compatibility, access and control, efficiency, equity, social vitality \\
\hline $\begin{array}{l}\text { Violich F. } \\
\text { [16] }\end{array}$ & 1983 & $\begin{array}{l}\text { Readability of the environment, freedom of choice, contrasting urban } \\
\text { forms, able to deliver the voice of past, to listen to the voices of the } \\
\text { past, paying attention to the native-region link. }\end{array}$ \\
\hline $\begin{array}{l}\text { Bentley I. } \\
\quad[17]\end{array}$ & 1985 & $\begin{array}{l}\text { Permeability, variety, flexibility, permeability, variability (form), } \\
\text { readability, flexibility, visual adaptability, richness, } \\
\text { possibility of personalizing. }\end{array}$ \\
\hline $\begin{array}{c}\text { Trancik R. } \\
\text { [18] }\end{array}$ & 1986 & $\begin{array}{l}\text { Keeping the movement connections, focusing on spaces, } \\
\text { continuity of the edges, controlling the axis of vision and perspective, } \\
\text { combining of the internal and external spaces. }\end{array}$ \\
\hline $\begin{array}{c}\text { Greene S. } \\
{[19]}\end{array}$ & 1992 & $\begin{array}{l}\text { Access and communication, diversity of users, security, consistency, } \\
\text { clarity, coherence, identity of unity, character, charm of scale, } \\
\text { proportion of visual function, vitality. }\end{array}$ \\
\hline $\begin{array}{l}\text { Haughton G, } \\
\text { Hunter C. } \\
\text { [20] }\end{array}$ & 1994 & $\begin{array}{l}\text { Democracy, permeability, security, economy and its tools, } \\
\text { consultation and participation of users, flexibility }\end{array}$ \\
\hline $\begin{array}{c}\text { Punter J. V, } \\
\text { Carmona M. [21] }\end{array}$ & 1997 & $\begin{array}{l}\text { Land use, pedestrian movement, patterns of behavior, riding movement } \\
\text { flow, permeability, public perception, qualitative evaluations, } \\
\text { operations, concept recalling, objective perspective, synthetic form }\end{array}$ \\
\hline $\begin{array}{c}\text { Pakzad J. } \\
{[22]}\end{array}$ & 2007 & Safety, vitality, space, flexibility. \\
\hline Habibi S. M. [23] & 2010 & $\begin{array}{l}\text { Diversity, safety and security, compatibility, social role, distinction and } \\
\text { character, legibility, permanence, spatial contrast, turning points, } \\
\text { pausing places, human scale, flexibility, weather conditions }\end{array}$ \\
\hline
\end{tabular}

are private according to the law, such as university campuses, sports fields, restaurants, cinemas and shopping centers can be also considered as parts of the public domain. In another classification, urban public spaces can be shown as hard and soft spaces. Hard spaces which are basically surrounded by the walls of nearby buildings, and soft spaces such as parks and natural and green routes which do not have any closeness and recognized borders and are under the domination of the surrounding environment [7].

\section{Concepts of Sustainable Architecture}

Sustainable architecture can be considered as one of contemporary critical events, a subset of sustainable designing, which is a wise reaction against industry era issues and problems. For example a considerable amount of fuel reserves are used in buildings, and this subject terminates ecological crisis in the present and future. Thus the necessity of creating more sustainable architecture, is well observable. As it is shown in Table 2, there are some key concepts in fields of sustainability and environment that should be taken into consideration. Sus- 
Table 2. Experts in the field of Sustainability and Environment [29].

\begin{tabular}{|c|c|c|c|}
\hline Theorist & Year & Text/theory & Key Concepts \\
\hline Chermayeff S. & 1964 & $\begin{array}{l}\text { Areas of public life and } \\
\text { private life }\end{array}$ & $\begin{array}{l}\text { Considering the factors threatening the } \\
\text { human environment in urban areas }\end{array}$ \\
\hline $\begin{array}{l}\text { Haughton G. } \\
\text { \& Hunter C. }\end{array}$ & 1994 & Sustainable Cities & $\begin{array}{l}\text { Constructive relations between buildings, } \\
\text { paths and open spaces }\end{array}$ \\
\hline Barton $\mathrm{H}$. & 1996 & $\begin{array}{l}\text { Sustainable settlements; } \\
\text { guidance for planners, } \\
\text { designers and developers }\end{array}$ & $\begin{array}{l}\text { Outdoor network to manage pollution and } \\
\text { increasing local green space }\end{array}$ \\
\hline Rogers R. & 1997 & Cities for a Small Planet & $\begin{array}{l}\text { The public social encouragement and } \\
\text { mobility factors }\end{array}$ \\
\hline
\end{tabular}

tainable architecture, as well as other categories of architecture, has its own principles and rules. Jong-Jin Kim and Brenda Rigdon (1998) proposed three principles of sustainability in architecture: Economy of Resources, Life Cycle Design and Humane Design, which each of them has its own special strategies [28]. Cognition and study of these schemes, helps the architects understand more about the environment which he will design.

\subsection{Economy of Resources (Stage of Providence in Resources)}

This principle consists considering suitable utilization of resources and nonrenewable energies, like fossil fuels, with the plan of reducing in consumption in one side, and is paying serious attention to control and utilize the natural resources as renewable and constant resources. For instance, one of the plenteous and permanent resources is the energy of the sun light, which is used in buildings for lightning and producing electricity by technology of photovoltaic cells. For controlling the resources, three strategies can be taken into consideration: Energy Conservation, Water Conservation and Material Conservation. As it is obvious, focusing on these three resources is because of the importance of them in constructing and controlling the buildings.

\subsection{Life Cycle Design (Stage of Returning to the Life Cycle)}

Second principle of sustainable architecture is stabled on the idea, which express that, a useful substance exchanges to another form, in a way its usefulness is not damaged, in other words, its usefulness is still kept. On the other hand, because of this "cradle-to-grave" approach, one of the architecture's tasks is to avoid pollution of the environment. For reaching this idea, this standard checks the building in three stages in sequence: pre-building, building and post-building. It has to be considered that all these stages are related to each other and there is not a distinctive bound between them. For example, it is possible to use the recycle materials of a building which belong to the post-building stage of the mentioned building, as primary materials in pre-building stage of another building.

\subsection{Humane Design (Stage of Designing for the Human)}

This principle is rooted in requirements that are necessary for preservation of 
ecosystem, which guarantees the human survival. Humane design is the last and maybe the most important principle of sustainable architecture. This principle includes three strategies of: preservation of natural conditions, urban design and site planning and human comfort, which focus on the increasing of the coexistence between buildings and the outdoor environment and between buildings and the people who use them. Indeed, it can be claimed that for reaching a sustainable architecture, designers have to combine and balance these stages, which are definers of a framework for sustainable design, in their works.

\section{Urban Space and Sustainable Development}

The origins of the formation of "development" return to the speech of famous president Truman in 1949. Historically, several factors led the development to be a global project. One, the renovations after the Second World War, and the other, second world war and debates of democracy and freedom against the fascism, which was infirming the intellectual justifications for colonization [30]. Simultaneous with the destroying of the colonization kingship system, countries entered world equations. In today conditions, rationality as a modern tool and pluralistic look to the concept of the development, has been caused a lot of social, economic and environmental harms. So the necessity of the sustainable developments in cities is becoming increasingly more important.

The classic definition of sustainable development, 'meeting the needs of present without compromising the ability of future generations to meet their needs', was produced by the Brundtland report [31]. Fatima Ghani (2012) believes that sustainable development presents an approach that can largely contribute to environmental protection [32]. As it is shown in Figure 1, Sustainable development is often presented as being divided into the economy, environment and society [33] [34]. These three factors play major roles in sustainable development.

Table 3 shows the three social, economic and environment factors' roles in pre-modern urban spaces, and it is illustrated in Figure 2 how, theoretically, pre-modern urban spaces altered to sustainable urban spaces.

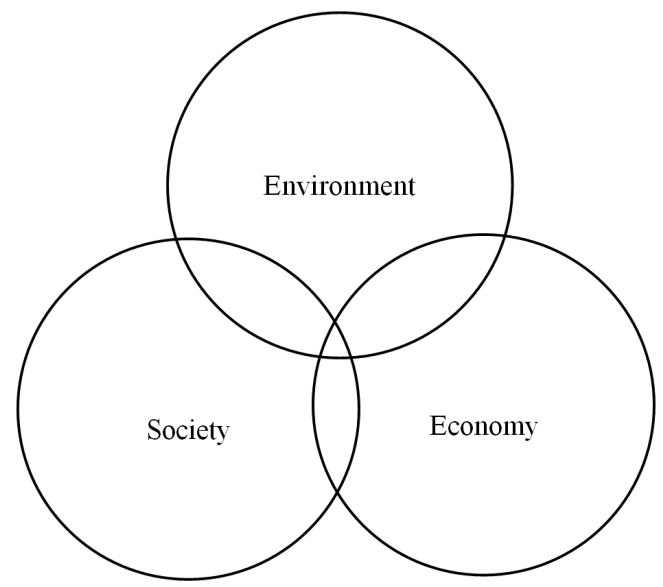

Figure 1. Common three-ring sector view of sustainable development. 


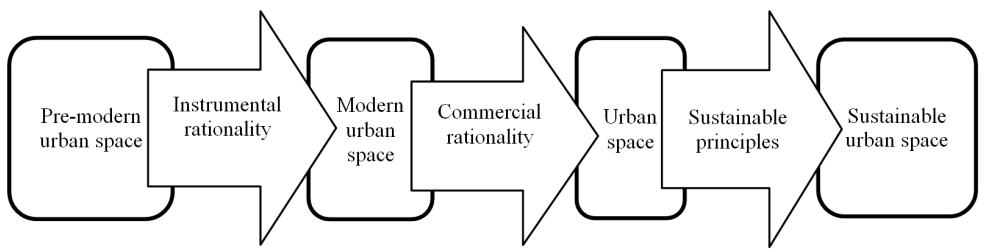

Figure 2. Role of urban areas in sustainable development [35].

Table 3. Pre-modern urban space and sustainable development components [35].

\begin{tabular}{|c|c|c|c|}
\hline $\begin{array}{c}\text { Social } \\
\text { components } \\
\text { The period } \\
\end{array}$ & Social & Economic & Environmental \\
\hline Greece & $\begin{array}{c}\text { Multi-functional urban } \\
\text { space/Democratic } \\
\text { space/Location of informal } \\
\text { meetings and communication } \\
\text { space/Space monopolized by } \\
\text { powerful minorities } \\
\text { /Heart of the city }\end{array}$ & Trading center & $\begin{array}{l}\text { Compatibility with the climate } \\
\text { and topography/Vernacular } \\
\text { Masonry }\end{array}$ \\
\hline Rome & $\begin{array}{l}\text { Places for religious meetings, } \\
\text { political events, sports and } \\
\text { informal meetings/Monitoring } \\
\text { the space through its design }\end{array}$ & Trading center & $\begin{array}{l}\text { Compatibility with the } \\
\text { climate and } \\
\text { topography/Vernacular } \\
\text { Masonry }\end{array}$ \\
\hline $\begin{array}{l}\text { Medieval } \\
\text { period }\end{array}$ & $\begin{array}{c}\text { The formation of space by the } \\
\text { church/Controlling } \\
\text { the space by the church }\end{array}$ & $\begin{array}{l}\text { Debilitation the role of } \\
\text { business in the } \\
\text { beginning and then } \\
\text { supporting it }\end{array}$ & $\begin{array}{l}\text { Reduction in soft urban spaces/ } \\
\text { Reducing the role of green } \\
\text { spaces in urban areas/Low light } \\
\text { in urban spaces }\end{array}$ \\
\hline $\begin{array}{l}\text { Renaissance } \\
\text { and Baroque }\end{array}$ & $\begin{array}{c}\text { Space as a place for public } \\
\text { displaying of glory and wealth } \\
\text { of the governor/Secular } \\
\text { urban space }\end{array}$ & $\begin{array}{l}\text { The emergence of the } \\
\text { bourgeois class and } \\
\text { playing role in urban } \\
\text { environment/Reduced } \\
\text { role for trade in urban } \\
\text { space }\end{array}$ & $\begin{array}{l}\text { Proceedings to overcome the } \\
\text { environmental determinism }\end{array}$ \\
\hline
\end{tabular}

\section{Explaining the Criteria of Sustainable Urban Public Spaces}

Existence of sustainable public spaces in cities is essential to prevent and predict social harms in society, in order to reduce depression and violence [36]. The quality of an urban space is reached from the results of the components, which by identifying the functions and appropriate impacts of each of these elements on the space, some solutions can be presented for improving the quality of the open space [37]. It can be said that the criteria of sustainable urban space are divided into two categories: the components which have direct effect on environmental, social and economic issues and the ones which have indirect effects. It is clear that the components of the second category also play major roles in social, economic and environmental sustainability classifications. Taking this to consideration, the following items are noted by this research, as the main instructions which are needed to have sustainable urban spaces.

\subsection{The Criteria with Direct Effects}

Social, economic and environmental instructions are listed below. 


\subsubsection{Social Instructions}

A Sustainable public space should be a space in which:

- People have social commitment and the sense of belonging for it and they are diligent to maintain it.

- People participate in urban activities and familiarity with each other and social interactions are made.

- People feel responsible for its hygiene and urban environment issues.

- Some solutions have been used to increase the vitality and safety of urban areas.

- Supporting the community groups, helping to solve social problems, social networking integration and awareness programs for the neighborhoods have been implemented.

- Reducing social abnormalities, promoting legalism in the city and neighborhoods, and the development and advancement of the habits under which people accept each other are promoted.

\subsubsection{Economical Instructions}

A Sustainable public space should be a space in which:

- People can Invest and contribute economic prosperity.

- Measures of energy, water and material conservation are observed.

- Productivity of local economy is possible.

- There is the capability for reusing environmental leftover.

- There is attraction which appeals non-native investors to the city and the region.

\subsubsection{Environmental Instructions}

A Sustainable public space should be a space in which:

- Design methods for re-usability and recyclability and also mitigation and adaptation to climate changes, including moving to a low carbon economy, are applied.

- Measures have been thought to reduce waste and pollution (smoke, sound pollution, etc.), utilize vernacular and eco-friendly construction materials and masonry, increase hygiene in spaces and educate people about environmental issues.

- Measures have been thought to have efficient climatic comfort in spaces and microclimates, and more efficient light absorbing, shadow casting, natural ventilation, vegetation and green areas and water management systems.

- The usage rate of renewable resources consumption would not exceed the rate of regeneration.

- The rates of waste generation from projects would not exceed the assimilative capacity of the environment.

- The depletion of the nonrenewable resources would require comparable development of renewable substitutes for that resource.

\subsection{The Criteria with Indirect Effects}

The following instructions define a sustainable urban space in three-functional, 
aesthetical and physical-categories.

\subsubsection{Functional Instructions}

- Terms of people convenience and comfort should be prepared such as being able for sitting and walking and meet every day needs of citizens.

- Accessibility for pedestrians and cyclists, connection to city services, transportation system nodes and the surrounding neighborhoods should be provided.

- Multi-purpose spaces should be designed for sports, entertainment, recreation and attractive activities.

- The location should be near main streets, in the busy city routes and daily activities centers.

\subsubsection{Aesthetical Instructions}

- The attractive space should be designed regarding to variation on the aesthetic quality of spaces, manner of night lighting on spaces and using colors to beautify spaces.

- Dynamism and vitality should be provided by using memorable and flexible spaces, through making the space suitable for different activities and creating diversity and happiness.

\subsubsection{Physical Instructions}

- The space should be readable and clear in minds of the users by using guiding elements in different locations, creating visual proportion in spaces and paying attention to human scale.

- Urban furniture should fit different ages and sex.

- Furniture arrangement, pavements and facades should be well designed.

- The space should be permeable and give people the power of moving between two locations and choosing their ways of movement.

- Safety and Security standards should be taken into consideration in night functions and disabled people's accessibility in order to increase social safety.

\section{Conclusion}

Sustainable development is an issue which becomes very useful in creating healthier cities and spaces, as the principles of sustainability is focusing on social, economic and environmental issues and natural resources preservation. If a design could be in the direction of sustainable development and, in simple words, with existing potentials it could respond to sustainable development needs, it could be evaluated as a sustainable design. Regarding to the fact that urban public spaces play major roles in the real city life, from socio-economic issues to cultural and environmental matters, sustainable development subjects can help the designers and managers have more efficient public spaces and, as the result, a city with higher standards to live. In this research, after studying urban public space and sustainable development topics, some important instructions which are helpful for designers regarding to sustainable development of urban public 
spaces, are suggested.

\section{References}

[1] Kurniaty, R. (2014) Local Elites and Public Space Sustainability: The Local Elite Roles in the Presence and Usage of Public Space in Malang Raya, Indonesia. Environmental Sciences, 20, 506-515. https://doi.org/10.1016/j.proenv.2014.03.063

[2] Garcia-Ramon, M.D., Ortiz, A. and Prats, M. (2004) Urban Planning, Gender and the Use of Public Space in a Peripherial Neighbourhood of Barcelona. Cities, 21, 215-223. https://doi.org/10.1016/j.cities.2004.03.006

[3] Rafieian, M. and Khodaei, Z. (2009) Evaluation Criteria And Standards Affecting The Satisfaction of Citizens in Urban Public Spaces. Journal of Rahbord, 53, $227-$ 248.

[4] Fathi, S. (2012) The Analysis of Social Relations in Sustainable Urban Space. Journal of Iranian Social Development Studies, 4, 47-64.

[5] James, P., Tzoulas, K., Adams, M.D., Barber, A., Box, J., Breuste, J., Elmqvist, T., et al. (2009) Towards an Integrated Understanding of Green Space in the European Built Environment. Urban Forestry \& Urban Greening, 8, 65-75. https://doi.org/10.1016/j.ufug.2009.02.001

[6] Abada, T., Hou, F. and Ram, B. (2007) Racially Mixed Neighborhoods, Perceived Neighborhood Social Cohesion, and Adolescent Health in Canada. Social Science \& Medicine, 65, 2004-2017. https://doi.org/10.1016/j.socscimed.2007.06.030

[7] Poormohammadi, M.R. and Kooshaneh, R. (2013) Evaluation and Analysis of Urban Public Spaces Using TOPSIS Model: Case Study: Tabriz. Regional and Urban Studies and Research Journal, 5, 52-73.

[8] Perovic, S. and Kurtovic Folic, N. (2012) Visual Perception of Public Open Spaces in Niksic. Social and Behavioral Sciences, 68, 921-933. https://doi.org/10.1016/j.sbspro.2012.12.277

[9] Jalaladdini, S. and Oktay, D. (2012) Urban Public Spaces and Vitality: A Socio-Spatial Analysis in the Streets of Cypriot Towns. Social and Behavioral Sciences, 35, 664-674. https://doi.org/10.1016/j.sbspro.2012.02.135

[10] Turel, H.S., Yigit, E.M. and Altug, I. (2007) Evaluation of Elderly People's Requirements in Public Open Spaces: A Case Study in Bornova District (Izmir, Turkey). Building and Environment, 42, 2035-2045. https://doi.org/10.1016/j.buildenv.2006.03.004

[11] Mohammadi, M., Azimi, M., Moghaddam, H. and Rafieian, M. (2013) Urban Public Spaces: Realization of Social Interactions in Historical Texture: A Case Study of Lar Old City. Journal of" Maremat \& Me' mari-e Iran", 2, 15-28.

[12] Sanei, M. and Khodadad, M. (2017) The Necessity of Collaboration between Technology and Architectural Design in Order to Improve the Quality of Urban Space. Proceedings of the International Conference on Modern Approaches in Science, Technology and engineering, Stockholm, 28 January 2017.

[13] Rafieian, M., Azimi, M. and Moghaddam, H. (2012) Quality Evaluation of Urban Zones in Success of Public Spaces by the Use of Veroni Weighted Diagram (VWD): A Case Study of Lar Old City. Amayesh Journal, 5, 33-49.

[14] Jacobs, J. (1993) Tod und Lebengrober Amerikanischer Stadte. Verlage uhlstein $\mathrm{GmbH}$, Frankfur.

[15] Lynch, K. (1972) The Openness of Open Space. Arts of Environment.

[16] Violich, F. (1983) Urban Reading and the Design of Small Urban Places: The Village 
of Sutivan. Town Planning Review, 54, 41-62. https://doi.org/10.3828/tpr.54.1.a32h36v52002154g

[17] Bentley, I., Alcock, A., Murrain, P., McGlynn, S. and Smith, G. (1985) Responsive Environments: A Manual for Designers. Architectural Press, London.

[18] Trancik, R. (1986) Finding Lost Space: Theory of Urban Design. Van Nostrand Reinhold, 74, 32-38.

[19] Greene, S. (1992) Cityshape. Journal of the American Planning Association, 58, 177-189. https://doi.org/10.1080/01944369208975792

[20] Haughton, G. and Hunter, C. (1994) Sustainable Cities. Jessica Kingsley Publishers/Regional Studies Association, London.

[21] Punter, J.V. and Carmona, M. (1997) The Design Dimension of Planning: Theory, Content and Best Practice for Design Policies. E \& FN Spon, London.

[22] Pakzad, J. (2007) Development of Thoughts in Urbanization (2): From Quantity to Quality. New Towns Civil Company, Tehran.

[23] Habibi, S.M. (2010) From Town to City: A Historical Analysis of the Meaning of the City and Its Form, [Az Shar ta Shahr]. Tehran University Press, Tehran.

[24] Rahnamai, M.T. and Ashrafi, Y. (2007) The Public Spaces of the City and Its Role in the Formation of the Civil Society from the Perspective of Urban Planning. Geography Quarterly Journal, 5, 14-15.

[25] Walzer, M. (1986) Pleasures and Costs of Urbanity. Dissent, 33, 470-475.

[26] Lipton, S. (2003) The Value of Public Space: How High Quality Parks and Public Spaces Create Economic, Social and Environmental Value.

[27] Woolley, H. (2003) Urban Open Spaces. Spon Press, London. https://doi.org/10.4324/9780203402146

[28] Kim, J.J. and Rigdon, B. (1998) Sustainable Architecture Module: Introduction to Sustainable Design. National Pollution Prevention Center for Higher Education. The University of Michigan, Michigan, 8-15.

[29] Kashani Jou, K.H. (2010) Recognition of Theoretical Approaches to Urban Public Spaces. Hoviate Shahr Journal, 4, 95-106.

[30] Wironen, M. (2007) Sustainable Development and Modernity: Resolving Tension through Communicative Sustainability. Master's Thesis, Lund University Center for Sustainability Studies, Lund University, Lund.

[31] Bruntland, G. (1987) Our Common Future: The World Commission on Environment and Development. Oxford University Press, Oxford.

[32] Ghani, F. (2012) Issues in Sustainable Architecture and Possible Solutions. International Journal of Civil \& Environmental Engineering, 12, 22.

[33] Hardi, P. and Zdan, T. (1997) Assessing Sustainable Development. International Institute for Sustainable Development, Winnipeg.

[34] West Midlands Round Table (2000) Quality of Life: the Future Starts Here. West Midlands Round Table for Sustainable Development, Solihull.

[35] Soltani, A. and Namdarian, A.A. (2011) The Analysis of the Role of City Places for Achieving the Constant Development of Cities and Explaining Communication $\mathrm{Pa}$ radigm. The quarterly of Baghnazar, 8, 8-13.

[36] Khodadad, M. and Sanei, M. (2016) Suggested Solutions to Improve Security in Urban Environment with an Approach of Sustainable Development. Proceedings of the 4th International Congress on Civil Engineering, Architecture and Urban Development, Shahid Beheshti University, Tehran, 27-29 December 2016. 
[37] Alipour, R., Khademi, M., Senmari, M.M. and Rafieian, M. (2012) Surveying Environment Quality Indicators in Detection of Interfering Priorities in the Deteriorated Fabric of Bandar Lengeh City. Scientific Journal of Bagh-E Nazar, 9, 13-22.

Submit or recommend next manuscript to SCIRP and we will provide best service for you:

Accepting pre-submission inquiries through Email, Facebook, LinkedIn, Twitter, etc. A wide selection of journals (inclusive of 9 subjects, more than 200 journals)

Providing 24-hour high-quality service

User-friendly online submission system

Fair and swift peer-review system

Efficient typesetting and proofreading procedure

Display of the result of downloads and visits, as well as the number of cited articles

Maximum dissemination of your research work

Submit your manuscript at: http://papersubmission.scirp.org/

Or contact wjet@scirp.org 